\title{
Education for voice: Challenges and opportunities
}

\author{
Dennis Shirley ${ }^{1}$
}

Published online: 29 April 2015

(c) Springer Science+Business Media Dordrecht 2015

In 1793 Immanuel Kant wrote a brief and powerful essay entitled "Answer to the Question: What is Enlightenment?" Kant's answer to his question is that for enlightenment or Aufklärung (literally, "clearing up" in the original German) to occur, it was necessary to have received an education that would enable one to exercise voice (1793/1999). This Erziehung zur Mündigkeit (literally, "education for voice") later became the title of a small volume of essays by Adorno (1971), who argued that the indispensable precondition of any genuine, humanistic education, must be to enable students to develop an informed criticism of their own society.

It may be too much to expect that in an age of such insistent pressure for schools to focus on human capital formation that one could study or perhaps even recover elements of such a philosophy of education. The "great convergence" (Mahbubani 2013) of economies, societies, and cultures around the world today ironically is bringing with it a subordination of critical citizenship skills, which are not even included in the literacy, mathematics, and natural science measurements of the Programme for International Student Assessments (PISA) of the Organization for Economic Cooperation and Development (OECD) for example. It is apparently entirely possible to be designated a "high performing" educational system on such measures, and to win the admiration of policy makers and think tank analysts around the world, without even the briefest apologies on behalf of regimes that not only disallow their students, but also their adults, to exercise voice (Zhao 2014).

Dennis Shirley

Shirleyd@bc.edu

1 Lynch School of Education, Boston College, 140 Commonwealth Avenue,

Campion Hall Chestnut Hill, MA 02467-3813, USA 
It is thus of utmost importance that the lead article in this issue of the Journal of Educational Change by Catharine Simmons, Anne Graham, and Nigel Thomas offers a countervailing perspective. The authors provide data from an Australian large-scale mixed methods research project on student voice related to their wellbeing. One provocative portion of this manuscript describes just how little we know about the ways in which student voice could be engaged to transform schools from places that are not only organized to attain measurable results but also to give students the opportunity to develop and pursue their own freely chosen academic interests. "Imagining an Ideal School for Wellbeing" provides a wealth of ideas for educators who wish to improve education not so much by pushing students to achieve externally determined goals as by providing platforms for them to develop their own projects in intellectually rigorous ways.

The second article in this issue, "Second Chance or No Chance?" by Brianna Kennedy-Lewis further develops this theme in relationship to a US school especially designed to serve students previously expelled from regular district schools. Of particular interest here is the role of educators' professional subcultures in either engaging the disaffected students or reinforcing the traditional instructional styles, curriculum and evaluation practices of schools with greater intensity. In this case, a school counseling subculture provided a safe haven for students in which they could share their challenges and establish relationships with trusted adults. This "developmentalist" subculture is especially treasured by marginalized youth and has shown promising results in the field of juvenile justice in the US (Lipsey et al. 2010). The academic subculture of teachers, however, was unable to respond to student voice with a curriculum that capitalized on their interests and experiences.

School subcultures often contain contradictory elements and it may be impossible to overcome them entirely. When subcultures clash overtly, however, student learning suffers. In the school studied by Kennedy-Lewis this unfortunately was the case. The school's administrative leaders were unable to bridge the two cultures, instead reinforcing the larger district, state, and national emphasis on academic achievement. Instead of education for voice, students experienced an education for silence, with a concomitant estrangement from the academic component of schooling.

"Second Chance or No Chance?" presents an unsympathetic portrait of classroom teachers, who are represented as preoccupied with the managerial dimensions of schooling rather than exploring the reasons why their students are oppositional in the first place. When read in companionship with this issue's third article, by Wendy Emo, on the topic of "Teachers' Motivation for Initiating Innovations," however, one is reminded that the pervasive uncertainty of teachers' instructional situations often calls forth conservative rituals and routines that can provide regularity but if left unchecked will produce rote learning that is neither inspiring nor effective. When student behavior is erratic, curriculum changes are frequent, and evaluation instruments shift from year to year one should not be surprised that teachers seek to preserve a minimal amount of consistency over those aspects of the instructional situation that they do control.

Emo's research on teacher motivation, conducted in the US, indicates that in spite or perhaps because of the many pressures placed upon teachers, they crave 
opportunities to innovate with their teaching. Simply implementing others' ideas, or doing what one has done in previous years, may help to assure an orderly environment, but it does not create the satisfaction of seeing one's students achieve at high levels. Even worse, simple compliance or repetition of lessons one already has taught many times can cause a pervasive sense of boredom that is not conducive to complete student engagement in learning. This theme of teacher boredom, while not as intellectually exciting as the literature on "alienated teaching" (MacDonald and Shirley 2009, p. 2), for example, is intriguing because even though it was not part of the original interview design, it surfaced with such frequency that it likely is of even greater significance than the researcher originally anticipated.

At this juncture an intriguing question arises: How is it possible to be bored in the instructional situation, where so many learners bring such diverse talents and questions to the task of learning? According to Kirsten Foshaug Vennebo and Eli Ottesen, part of the problem may reside in the ways that teachers themselves overlook opportunities in which students could develop their own skills independently and perhaps even attain a stage of proficiency in one arena that is in advance of their teachers. Vennebo and Ottesen, in "The Emergence of Innovative Work in School Development," in the fourth article in this issue, studied the manner in which educators conceptualized the implementation of new software in Norwegian upper secondary schools. Their research design followed in fine-grained detail how educators espoused and adapted diverse perspectives, capitalizing especially upon the open and indeterminate field of educational technology. While there are many surprises in their findings, perhaps the most significant concerns the difficulties that educators had acknowledging that their students' technological expertise might surpass their own and could provide a fertile point of departure for allowing students to innovate in schools.

Could it be that educators' fragile sense of professional expertise unconsciously impedes their ability to unleash students' talents and curiosity, even though it is widely known that students often are far ahead of their faculty when it comes to their everyday knowledge of new digital technologies? Furthermore, could it be the case that when educators are given opportunities to innovate, they unconsciously reproduce traditional transmission models of education such that their students ironically miss out on the innovative potential of novel situations? These are troubling questions that educators must consider when reading this meticulously researched and finely theorized article.

The findings of the Norwegian team are similar to those in the Kennedy-Lewis article on "Second Chance or No Chance?," in that in each instance one confronts the culpability of educators themselves in failing to capitalize fully on their instructional opportunities. One is reminded of one of Shakespeare's crueler lines, from King Lear: "The gods are just, and of our pleasant vices/Make instruments to plague us" (Act V, Scene III, lines 198-199). Both articles indicate that it is not simply greater voice that may be needed in educational change today, but rather greater skills in listening to our students and attending to our colleagues. The ability to open one's mind and heart to diverse perspectives, including those that could challenge one's own expertise and status, appears to be badly needed in the uncertain profession that is education. 
Realistically, however, it is difficult to be open-minded to others about the core purposes of education if one's own understanding is weak. The disconcerting finding of the fifth article in this issue, conducted by a research team at the University of Alabama at Birmingham, is that many US educators, at least in the sampled population, are uncertain about their institutions' missions, vision, values, and goals. Furthermore, only $10 \%$ of those surveyed identified high levels of student learning as pertinent to their mission. Organizational research literature (Bryson 2004; Kaufman 1992; Mintzberg 1994) indicates that without a clear sense of purpose, organizations can easily fail to engage their employees and to achieve excellence. By failing to crystallize the purpose of education as the promotion of learning, a host of secondary considerations enter into the field that are often extraneous to the core enterprise and threaten goal diffusion. Lacking a focus, educators fall back upon the habitus of everyday life in schools in which compliance with rules and regulations take precedence over the always fragile and often onerous tasks of teaching and learning.

Taken together, the five articles in this issue of The Journal of Educational Change indicate that when it comes to "education for voice," the profession itself must have the courage to face its current limitations and to do so whether they are externally imposed or internally generated. Viewed optimistically, there are a plenitude of venues that open themselves as opportunities for renewing practice and deepening learning. First, educators can attend more deeply to student voice and to use it as a fulcrum for school development. Second, we can listen more carefully to one another as colleagues and constantly check to ascertain whether we are simply re-inscribing long established routines that merit questioning and transformation rather than tenacious doubling-down. Finally, the profession will benefit by returning to investigate the deeper purposes of education so that our students are reminded again and again that all of our work is organized around their learning, and ultimately their flourishing.

\section{References}

Adorno, T. (1971). Erziehung zur Mündigkeit: Vorträge und Gespräche. Frankfurt: Suhrkamp.

Bryson, J. M. (2004). Strategic planning for public and nonprofit organizations: A guide to strengthening and sustaining organizational achievement (3rd ed.). San Francisco: Jossey-Bass.

Kant, I. (1793/1999). Beantwortung der Frage: Was ist Aufklärung? In: H. D. Brandt (Ed.) Was ist Aufklärung? Ausgewählte kleine Schriften. Hamburg: Felix Meiner Verlag.

Kaufman, R. (1992). Strategic planning plus: An organizational guide. Newbury Park, CA: Sage.

Lipsey, M. W., Howell, J. C., Kelly, M. R., Chapman, G., \& Carver, D. (2010). Improving the effectiveness of juvenile justice programs. Washington, D.C.: Georgetown Center for Juvenile Justice Reform.

MacDonald, E., \& Shirley, D. (2009). The mindful teacher. New York, NY: Teachers College Press.

Mahbubani, K. (2013). The great convergence: Asia, the west, and the logic of one world. New York: Perseus.

Mintzberg, H. (1994). The rise and fall of strategic planning. New York: Free Press.

Zhao, Y. (2014). Who's afraid of the big bad dragon? Why China has the best (and worst) education system in the world. San Francisco: Jossey-Bass. 